International

Medical Society

http://imedicalsociety.org

\title{
Care Quality to
}

\section{Physiological Delivery at a University Hospital}

\begin{abstract}
Alexandra do Nascimento Cassiano, Milena Gabriela dos Santos Silva², Flávia Andréia Pereira Soares Santos ${ }^{1}$, Flávio Lopes Alves ${ }^{1}$, Mércio Gabriel de Araújo ${ }^{1}$, Kátia Cristina Araújo Nascimento de Oliveira1, Bertha Cruz Enders ${ }^{1}$, Marquiony Marques dos Santos ${ }^{1}$, Nilba Lima de Souza ${ }^{1}$
\end{abstract}

\section{Abstract}

The research aims to evaluate the quality of care on a physiological delivery in a University Hospital. Cross-sectional analytical study of quantitative approach carried out with 127 mothers of physiological vaginal deliveries during May-June 2015. This is a cross-sectional study with a quantitative approach, carried out during May and June 2015 in Santa Cruz, Rio Grande do Norte, Brazil. The sample was obtained in a conventional manner, with 127 mothers of physiological vaginal deliveries interviewed through the inclusion and exclusion criteria. Data were analyzed using descriptive statistics with the use of SPSS 20.0. The study followed the recommendations of Resolution 466/12 of the National Health Council, with opinion approved by the Research Ethics Committee1,034,398, and C.A.A.E. 43945415.4.0000.5568. The average value of Bologna Index was 3.60, corresponding to a good evaluation score. It was verified the frequent use of best practices by the World Health Organization, which comprises the Category A while it was identified the low employment of categories B, C, and $D$, estimated as harmful, ineffective without sufficient evidence or employed improperly. It is considered that in the studied reality the care was judged as a good quality, especially as regards the adoption of recommended procedures. Knowledge of factors that influence the disqualification of delivery care has allowed the development of strategies to minimize their impact.
1 Federal University of Rio Grande do Norte. Rio Grande do Norte, Brazil.

2 Secretary of Health of the City of Parelhas. Rio Grande do Norte, Brazil.

\section{Contact information:}

Alexandra do Nascimento Cassiano.

Address: Federal University of Rio Grande do Norte. Department of Nursing. Rio Grande do Norte, Brazil.

Tel: 04184999502265.

$\risingdotseq$ anc_enfa@hotmail.com

\section{Keywords}

Natural Childbirth; Midwifery; Health Services Research; Obstetric Nursing. 


\section{Introduction}

From the home delivery, experienced within the family and carried out almost exclusively in the mother's house; to the doctor-hospital event, seen as an amenable process to interventions [1], attention to birth became guided in advances and changes in the social and science context.

In the past, childbirth was a responsibility only for women, accompanied by midwives or godmothers, trust people for the pregnant woman and experience recognized by the community, although not dominating scientific knowledge. Reasons involving the exposure of female intimacy and the male presence were not seen as a good prestige, as the devaluation of childbirth as a medical activity [2].

Hospitalization came in the twentieth century, in the 40s, before the scientific innovations such as reducing hospital risks, expansion of possibilities of intervention and enhancement of maternal and child health to reduce the high mortality rates, and be as a strategy to control and monitor the population development [3, 2].

This reality favors the submission and loss of autonomy of women during birth [2] and opened room for the indiscriminate execution procedures from its institutionalization.

Meanwhile, the health care model follows the paradigm technocrat, characterized by high rates of interventions performed routinely and without justifiable clinical indication, as an example of unnecessary cesareans, food restriction, routine use of episiotomy, Kristeller maneuver, forceps, oxytocin, imposing supine positions, among others $[4,5,6]$. Interventions are often unnecessary and harmful in childbirth are considered as physiological, that is, those in which there is a failure in the progression of labor or obstetrical complications, and which should occur naturally and spontaneously [4].

Due to the consequences of medicalization brought to the health of women and the newborn, from the 1980s, in Brazil, and the world, the delivery care has become the stage of discussion among public health professionals to modifying the paradigms of obstetric medicine $[6,7]$.

Discussions that led to the development of Good Care Practices to Labor and Delivery (BPAPN) were established by the World Health Organization (WHO) These correspond to four ranked categories as follows: Category $A$ : demonstrably useful practices and to be stimulated; Category B: clearly harmful or ineffective practices that should be eliminated; Category C: practices that there is insufficient evidence to support a clear recommendation, and that should be used with caution until further research clarifying the problem, and Category D: practices often used improperly [8].

The Bologna Index (BI) is the first instrument to assess the quality of care of normal delivery in a quantitative manner, which consists of five variables: accompanying presence, partograph use, absence of stimulus [use of oxytocin, forceps, Kristeller maneuver], adoption of non-supine position and contact by the mother's skin with the newborn in the first hour of life [5].

Each variable gets a score being assigned "1" if present and " 0 " if absent. The value of the score is obtained by the sum of notes where the value " 0 " is considered as the lowest quality and " 5 " as the best quality [5].

The above index is a sustained instrument on the assumption that the delivery should be used without medication technologies and evidence-based [9].

Thus, currently recommended indicators for the assessment of delivery care correspond to the comparison between the $\mathrm{BI}$ and the $\mathrm{WHO}$ recommendations, which are, parameters already used in other works $[10,5,6]$. Thus, the use of such references allows a concise judgment on the occurrence and frequency of obstetrical practices performed in different settings, provided that anchors the use of the method studied [5].

Thus, the search of the hypothesis that inadequate quality of delivery care is related to a low value of $\mathrm{BI}$ and the minimum use of category $\mathrm{A}$ practices 
associated with increased employment procedures in categories B, C and D. The research aims to assess the quality of care of physiological delivery in a University Hospital (UH).

\section{Methods}

Cross-sectional study with a quantitative approach, performed in a UH in Santa Cruz, Rio Grande do Norte (RN), Brazil.

The population corresponded to the number of physiological births of mothers assisted in the institution, with an average of 83 deliveries per month. The sample was obtained by convenience, with collection during the days and to consider the inclusion and exclusion criteria.

The choice for convenience sample came from the fact that the institution does not have data available on some physiological births, distinguishing them from dystocia, post-term, and early induction.

The mothers with a maximum of 48 hours after the usual risk of delivery were included, whose children were born by trans-pelvically route with early spontaneous labor at term and without dystocia. Those who have the following conditions were excluded: deliveries at home, in the way to the hospital or admitted during the expulsive period.

Data were collected in May-June 2015 through a structured instrument made up of the features of the socio-demographic profile [age, city of residence, family income, education, marital status] and obstetrical postpartum women (gestational age at birth, parity, type of previous birth), the variables that make up the $\mathrm{BI}$ and the BPAPN recommendations.

The unit's record book and medical records of patients were consulted, as well as the direct interview was conducted with mothers in pre-delivery rooms, Childbirth and Postpartum (PPP) and Rooming-inn (RI). The process of information was initiated after the clarification of the objectives, risks, and benefits of participation in research, in addition to signing the Informed Consent Form (TCLE).

The data were analyzed using descriptive and inferential statistics. The data were analyzed using descriptive statistics, calculated mean values, frequencies and percentages, which were presented descriptively and tables. The categorization of values regarding age, years of education, income and gestational age were based on theoretical references.

The $\mathrm{BI}$ was categorized to consider the median value of all births analyzed. Thus, the following values were observed: up to 3 , as lower quality, and $>3$, as best quality.

The research followed the recommendations of Resolution 466/12 of the National Health Council (CNS) of Brazilian, with opinion approved by the Research Ethics Committee (CEP), the Faculty of Health Sciences in Trairí (FACIS), RN, Brazil, with number 1,034,398, and CAAE 43945415.4.0000.5568.

\section{Results}

During the months of collection, there were 223 deliveries, and 127 mothers were selected to interview after meeting the inclusion and exclusion criteria. Thus, eight women were excluded by dystocia, 25 by induction, two by being pre-term and 35 for admission in the expulsive period, obtaining a sample equivalent to $88 \%$ of the eligible population.

The socioeconomic and obstetric characteristics of the interviewed mothers indicate that most of the women were aged up to 20 years old, with an average of nine years of education and a minimum wage of family income. Regarding marital status, predominated women with a stable union and as parity, the largest group corresponded to multiparous. The Gestational Age (GA) has averaged 40 weeks and one day, but with a higher proportion of women who gave birth in the period considered at term. Regarding the obstetrical history, those who experienced vaginal delivery prevailed. 
An important fact was that from the investigated births, a significant number were performed by nurses $(47.2 \%)$, with relatively close value to those assisted by doctors. The women came from 31 municipalities in the states of RN, distributed in the regions of Trairí, Potengi, Seridó, Metropolitana, Sertão Central Coast and Agreste Litoral, and a municipality of Paraíba.

As the average value of $\mathrm{BI}$, it was found a score of 3.60. Thus, based on the categorization of content (up to 3 and $>3$ ), the care delivery in the context under consideration had a good assessment as to its quality.

Regarding BPAPN in Table 1, the frequencies are distributed according to the categories (A, B, C and D).

Table 1. Absolute frequency and percentage of variables that make up the categories $A, B, C$ and D of Good Practices Attention to Labor and Delivery. Santa Cruz, Rio Grande do Norte, Brazil. 2015.

\begin{tabular}{|c|c|c|c|c|}
\hline \multirow{2}{*}{ Categories } & \multicolumn{2}{|c|}{ Yes } & \multicolumn{2}{|c|}{ No } \\
\hline & $\mathbf{N}$ & $\%$ & $\mathbf{N}$ & $\%$ \\
\hline \multicolumn{5}{|c|}{ A: Practices demonstrably useful and to be stimulated } \\
\hline $\begin{array}{l}\text { Respect for privacy in the place of } \\
\text { birth }\end{array}$ & 126 & 99.2 & 1 & 0.8 \\
\hline Empathic support by professionals & 124 & 97.6 & 3 & 2.4 \\
\hline Fluid offer during labor and delivery & 127 & 100 & 0 & 0 \\
\hline $\begin{array}{l}\text { Providing information to the } \\
\text { pregnant woman }\end{array}$ & 125 & 98.4 & 2 & 1.6 \\
\hline Providing information to the partner & 125 & 98.4 & 2 & 1.6 \\
\hline Multi-professional monitoring & 127 & 100 & 0 & 0 \\
\hline $\begin{array}{l}\text { Fetal monitoring by intermittent } \\
\text { auscultation }\end{array}$ & 124 & 97.6 & 3 & 2.4 \\
\hline WHO partograph use & 38 & 29.9 & 89 & 70.1 \\
\hline Companion present during labor & 125 & 98.4 & 2 & 1.6 \\
\hline $\begin{array}{l}\text { Use of non-pharmacological methods } \\
\text { of pain relief }\end{array}$ & 83 & 65.4 & 44 & 34.6 \\
\hline Delivery in non-supine position & 124 & 97.6 & 3 & 2.4 \\
\hline $\begin{array}{l}\text { Oxytocin uses in placental delivery } \\
\text { period }\end{array}$ & 127 & 100 & 0 & 0 \\
\hline $\begin{array}{l}\text { Early contact between mother and } \\
\text { baby }\end{array}$ & 120 & 94.5 & 7 & 5.5 \\
\hline
\end{tabular}

\begin{tabular}{|c|c|c|c|c|}
\hline \multirow{2}{*}{ Categories } & \multicolumn{2}{|c|}{ Yes } & \multicolumn{2}{|c|}{ No } \\
\hline & $\mathbf{N}$ & $\%$ & $\mathbf{N}$ & $\%$ \\
\hline \multicolumn{5}{|c|}{ B: harmful or ineffective practices to be eliminated } \\
\hline Use of enema & 0 & 0 & 127 & 100 \\
\hline Use of trichotomy & 0 & 0 & 127 & 100 \\
\hline $\begin{array}{l}\text { Intravenous infusion in labor and } \\
\text { delivery }\end{array}$ & 73 & 57.5 & 54 & 42.5 \\
\hline Rectal examination & 42 & 33.1 & 85 & 66.9 \\
\hline Use of oxytocin during labor & 70 & 55.1 & 57 & 44.9 \\
\hline Use of lithotomic position & 1 & 0,8 & 126 & 99.2 \\
\hline $\begin{array}{l}\text { Perineal massage during the } \\
\text { expulsion period }\end{array}$ & 61 & 48.0 & 66 & 52.0 \\
\hline
\end{tabular}

C: Practice without sufficient evidence to support a clear recommendation and which should be used with caution until further research clarifying the matter

\begin{tabular}{l|c|c|c|c|c|}
\hline $\begin{array}{l}\text { Early amniotomy in the dilation } \\
\text { period }\end{array}$ & 1 & 0.8 & 126 & 99.2 \\
$\begin{array}{l}\text { Pressure in the uterus background in } \\
\text { the expulsion period }\end{array}$ & 14 & 11.0 & 113 & 89.0 \\
$\begin{array}{l}\text { Use of forceps } \\
\text { Active management of the placenta } \\
\text { during placental delivery }\end{array}$ & 1 & 0.8 & 126 & 99.2 \\
$\begin{array}{l}\text { D: Practices often used improperly } \\
\begin{array}{l}\text { Water and food restriction during } \\
\text { labor }\end{array}\end{array}$ & 0 & 0 & 127 & 124 & 97.6 \\
$\begin{array}{l}\text { Repetitive and frequent vaginal } \\
\text { examinations performed mainly by } \\
\text { more than a professional }\end{array}$ & 61 & 48.0 & 66 & 52.0 \\
\hline $\begin{array}{l}\text { Transfer to another room at the } \\
\text { beginning of the expulsive period }\end{array}$ & 0 & 0 & 92 & 100 \\
\hline $\begin{array}{l}\text { Bladder catheterization } \\
\text { Episiotomy }\end{array}$ & 3 & 2.4 & 124 & 97.6 \\
\hline
\end{tabular}

Source: Data collected by the author.

The frequent use of best practices by WHO was verified, which make up the Category A. However, there is a low use of the partograph. For categories $B, C$ and $D$, classified as harmful, ineffective, without evidence or used improperly, the low use of these behaviors has been identified.

In general, it is observed that the variables highlighted were the supply of liquid, multi-professional monitoring and use of oxytocin in placental delivery, considered fundamental practices that should be encouraged, then being part of Category A. With percentage near all deliveries, there was a 
Table 2. Statistical analysis of the correlation between Bologna Index and the variables that make up the Good Practices Attention to Labor and Birth WHO. Santa Cruz, Rio Grande do Norte, Brazil. 2015.

\begin{tabular}{|c|c|c|c|c|c|c|c|c|}
\hline \multirow{3}{*}{ Variable } & \multirow{3}{*}{ Category } & \multicolumn{4}{|c|}{ Bologna Score } & \multirow{3}{*}{$\mathbf{R P}$} & \multirow{3}{*}{ IC } & \multirow{3}{*}{$\begin{array}{l}\text { Value } \\
p\end{array}$} \\
\hline & & \multicolumn{2}{|c|}{ Até 3} & \multicolumn{2}{|c|}{$>3$} & & & \\
\hline & & $\mathbf{N}$ & $\%$ & $\mathbf{N}$ & $\%$ & & & \\
\hline \multirow{2}{*}{ Partograph } & No & 56 & 62.9 & 33 & 37.1 & \multirow{2}{*}{2.99} & \multirow{2}{*}{$1.58-5.646$} & \multirow{2}{*}{$<0.001$} \\
\hline & Yes & 8 & 21,1 & 30 & 78.9 & & & \\
\hline \multirow{2}{*}{$\begin{array}{l}\text { Not Pharmacological method to pain } \\
\text { relief }\end{array}$} & No & 27 & 61.4 & 17 & 38.6 & \multirow{2}{*}{1.38} & \multirow{2}{*}{$0.98-1.925$} & \multirow{2}{*}{0.072} \\
\hline & Yes & 37 & 44.6 & 46 & 55.4 & & & \\
\hline \multirow{2}{*}{ Skin contact } & No & 5 & 71.4 & 2 & 28.6 & \multirow{2}{*}{1.45} & \multirow{2}{*}{$0.88-2.401$} & \multirow{2}{*}{0.252} \\
\hline & Yes & 59 & 49.2 & 61 & 50.8 & & & \\
\hline \multirow{2}{*}{ IV infusion } & Yes & 56 & 76.7 & 17 & 23.3 & \multirow{2}{*}{5.18} & \multirow{2}{*}{$2.70-9.95$} & \multirow{2}{*}{$<0.001$} \\
\hline & No & 8 & 14.8 & 46 & 85.2 & & & \\
\hline \multirow{2}{*}{ Oxytocin } & Yes & 55 & 78.6 & 15 & 21.4 & \multirow{2}{*}{4.98} & \multirow{2}{*}{$2.70-9.18$} & \multirow{2}{*}{$<0.001$} \\
\hline & No & 9 & 15.8 & 48 & 84.2 & & & \\
\hline \multirow{2}{*}{ Kristeller } & Yes & 13 & 92.9 & 1 & 7.1 & \multirow{2}{*}{2.06} & \multirow{2}{*}{$1.60-2.64$} & \multirow{2}{*}{0.001} \\
\hline & No & 51 & 45.1 & 62 & 54.9 & & & \\
\hline \multirow{2}{*}{ Touches } & Yes & 33 & 54.1 & 28 & 45.9 & \multirow{2}{*}{1.15} & 002162 & ברבי \\
\hline & No & 31 & 47.0 & 35 & 53.0 & & $0.8<-1.63$ & $0.4 \angle L$ \\
\hline Massage on the nerineum & Yes & 37 & 60.7 & 24 & 39.3 & 148 & $18(\mathrm{r})+2$ & 0.026 \\
\hline IViassage on the permeum & No & 27 & 40.9 & 39 & 59.1 & 1.48 & $1.04-2.11$ & $0.0<0$ \\
\hline Fnisiotomy & Yes & 20 & 62.5 & 12 & 37.5 & 125 & 0 a 100 & 11 \\
\hline Episiotomy & No & 44 & 46.3 & 51 & 53.7 & 1.35 & $0.90-1.90$ & 0.113 \\
\hline
\end{tabular}

Source: Data collected by the author.

respect for privacy, the partner's presence, providing information to the laboring woman and companion, empathic support of professionals, adoption of non-supine positions at delivery, fetal monitoring by intermittent auscultation and skin contact between the mother and the baby.

On the other hand, in this same category, the use of non-pharmacological methods of pain relief $(65.4 \%)$ and the use of the partograph (29.9\%) corresponded to the lowest percentages. On Category $B$, practices considered harmful or ineffective, only enema and trichotomy were not identified. In the same category, it was found the presence of variables such as intravenous infusion in labor and delivery and administration of oxytocin, which had a higher occurrence of $50 \%$.

The Category $C$, corresponding to the practices to be used with caution, it is observed that they had low use. However, it was found the use of pressure in the back of uterus in the expulsive period and the application of forceps.

Finally, in Category D, the use of repeated and frequent vaginal examinations was highlighted especially by more than one professional, which was reported by nearly half of respondents. The episiotomy was identified in $25.2 \%$ of cases, however, without saying it has a possible use.

Based on the analysis of the correlation between categories of $\mathrm{BI}$ with the variables of BPAPN (Table 2), it was found that, when the delivery assessed as lower quality, not using the Partograph, maintenance intravenous infusion, the use of oxytocin and the use of Kristeller maneuver were significant to determine the disqualification of care.

Although not statistically significant values have not been presented, perineal massage in the expul- 
sive period, the restriction of skin contact between mother and baby, non-pharmacological methods use and the use of episiotomy presented relevant percentages values as the trend for a worst evaluation.

\section{Discussion}

The findings of the study allowed to infer that the quality of delivery care at the university hospital was considered appropriate, in view of the satisfactory value of the $\mathrm{BI}$ and the frequent use of practices that make up the category to the detriment of practices in categories $B, C$ and $D$. These categories $B$, $C$ and $D$ were associated with a poorer quality of delivery care.

In this reality, there is the presence of the nurse as a professional responsible for conducting the physiological deliveries. This is a particular and differentiated reality before other obstetrical care institutions, where most births are attended by obstetricians [11-12], and pointing to care transition model to health doctor-centered to multiprofessional care.

In a cross-sectional study, where $56.5 \%$ of births were attended by midwives, it was suggested that models involving the participation of the professional have lower rates of interventions [13], and are more likely to evolve into spontaneous labor and high sense of autonomy for the patient [12, 14, 15].

Nurses are gaining space in assisting the birth since the late 80's and had further consolidation with the implementation of the law of professional practice which provides for the participation of the obstetric nurse in attendance to prenatal, delivery and postpartum [16]. Still at this point of view, since the 90s, the public policy childbirth care humanization has encouraged the inclusion of nursing in monitoring the usual risk of birth to promote changes in care model [16].

Regarding the quality of delivery care in the hospital investigated, it was considered appropriate, in view of the satisfactory value of the $\mathrm{BI}$ and the frequent use of practices that make up the category to the detriment of practices in categories $B, C$ and $D$. These categories $B, C$ and $D$ were associated with a poorer quality of delivery care.

Different to the reality of the institution above; other contexts found a high frequency of not encouraged practices and limited use of what is recommended $[5,17]$. The evidence is confirming the quality of assistance under study.

Regarding the $\mathrm{BI}$, an average considered as good evaluation, with a value close to that found in this study. It was found in a survey conducted in Sweden which obtained a score of 3.81 [18]. In the city of Goiânia (GO)/Brazil, a study conducted in the city's hospitals found that most of the evaluated births had lower scores or equal to 1 and an average of 1.04, a number that denotes the inadequacy of quality in such places [5]. Similarly, another study conducted in a university hospital had an average value of 1.95 [19].

A similar study implemented in a maternity hospital in Omdurman in Sudan also found a low value for $\mathrm{BI}$ and considered that the reasons for this outcome are related to resource and training service providers [9]. The comparative analysis of the evidence cited, and the value found in the hospital study confirms the quality of care in the institution, emphasizing the importance of adopting humane practices and with minimal intervention.

The finding that all deliveries were assisted by multidisciplinary team is also an advantage, because the presence of doctors and/or obstetric nurses, a pediatrician, physiotherapist, psychologist, nutritionist, social workers and others, constitutes as potential for promoting health binomial during the antepartum, delivery and postpartum, with a recommendation recommended by $\mathrm{WHO}$ and $\mathrm{MS}$ [20].

The variables regarding the privacy and supply of liquid and food were reported in the context under study. On the first, it is pertinent to reflect 
on this statement since the hospital culture allows the presence of several professionals and students in assisting women in labor, although other studies have also identified respect for the privacy of prevailing the parturient care [17]. Since the supply of liquids and light food has been established as a common approach in Brazilian hospitals, although dietary restriction in routine some 21 services can be verified.

Even with a good overall evaluation, the low use of the partograph in monitoring the evolution of labor emerges as a weakness of the service, which shows the need to instigate the adoption of the same by the professionals of the institution.

Although the available evidence highlights the importance of the partograph in conducting regular risk deliveries by allowing the differentiation of their progression in normal or abnormal and the application of relevant interventions [22, 23], its use varies in different realities, with low percentage $(2.4 \%)$ to values that reach $100 \%$ of births attended with the instrument $[6,17]$.

A strong point of care found in this study corresponded to the partner's presence in all cases evaluated. In Brazil, the law 11.108/2005 ensures the presence of a laboring woman's choice of companion throughout hospitalization, which is a woman's right and responsibility of the institutions.

Despite the almost ten years of the law, a recent survey found that women who experience vaginal delivery, residing in the Midwest, are of low social class and education, brown and black, multiparous and SUS users were more likely to this right deprivation [24]. Similarly, hospitals that did not have adequate infrastructure, which did not have a permission policy, those who were not part of the network "Child-Friendly Hospital" or did not have the title "Galba de Araújo" were associated with higher chances of the absence of accompanying [24].

As for non-pharmacological methods of pain relief, such as the warm bath, lumbosacral massage, walking and a Swiss ball, the scientific literature has discussed their effectiveness as techniques to reduce the perception of pain caused by uterine contractions and to contribute to the evolution of delivery $[12,25]$. Despite the benefits, few institutions offer them routinely, or at most has a discrete application, but that does not reach $50 \%$ of pregnant women assisted [21]. Well below the percentage value found in the hospital.

Based on the recommendations of the $\mathrm{WHO}$ and MS, administration of $10 \mathrm{IU}$ of oxytocin via intramuscular (IM) or intravenous (IV) in the third quarter occurred in all pregnant women [33]. The use of uterotonic prophylaxis of Postpartum Hemorrhage (PPH) has a recommendation level $A$ because its administration comes to reduce by $40 \%$ the incidence of postpartum hemorrhage [26].

Another indication of the $\mathrm{WHO}$ is skin contact between mother and newborn soon after birth, however, is still not a routine conduct in institutions. A study carried out in Brazil 2011 to 2012, found that in the South, this approach occurred in 32\% of deliveries and the Northeast, their frequency was only $28 \% 27$. In the context studied, early contact was present in almost all deliveries.

Maintaining venipuncture during the birth process with an infusion of glucose solutions has long been a common behavior in obstetrics, sub justification to promote energy support, reduce the risk of maternal acidemia and maintain the acid-base fetal balance $[21,28]$. However, studies recommend that the infusion of fluids should not be routine because it is a limited intervention for specific indications such as in cases of hypotension and bleeding [23].

In general, the use of oxytocin was followed by the maintenance of the venipuncture by the fact that their administration route is parenteral, and showed occurrence higher than the recommended value (10 to 20\%) when this is justified only in cases where it is necessary dyskinesias of correction [21]. In other services, the high use of 
the drug dominates, despite the North, Northeast and Midwest regions of Brazil were identified as the areas of the country that less administer the drug $[5,21,29,17]$.

Although amniotomy is a procedure performed in various research $[6,29,21]$, such a technique had minimal occurrence in $\mathrm{UH}$, denoting its proper use.

The Kristeller maneuver in the expulsive period is one of the most controversial procedures, both in the general population, as scientific as it is still a controversial gimmick by the lack of scientific evidence about its applicability and represent a high level of interference in childbirth [5, 29]. Above all, the main complications associated correspond to maternal health problems such as liver damage, a higher degree lacerations, uterine rupture and neonatal complications such as fractures and brain injuries [29].

As for perineal massage in the expulsive period and episiotomy, evidence suggesting is given that, when they are used without criteria, such procedures are risk factors for disorders of the pelvic diaphragm postpartum [30]. Even the WHO recommendations that episiotomy has an estimated ratio of no more than $10 \%$, it is not uncommon to identify their indiscriminate use, especially in deliveries performed by doctors $[5,12]$.

Finally, a large national study, entitled "Born in Brazil", carried out from 2011 to 2012, concluded that in the reality of Brazilian hospitals, a very small percentage of low-risk women $(8.8 \%)$ can have a natural delivery [38]. The same study points out that in countries like Australia and England have values reaching percentages ranging from $15 \%$ to $41.8 \%$ 31.

Therefore, the results presented here are rare to design the construction of a care model aimed at multi-professional work, reducing interventions, empowerment of women and the empowerment of their autonomy in the process. However, this is not the reality of all Brazilian women.

\section{Conclusions}

The quality of delivery care in the hospital under study was considered as adequate, given the satisfactory value of the $\mathrm{BI}$ and the frequent use of practices that make up the category to the detriment of practices in categories B, C, and D. It is emphasized that these latter were associated with a worse quality.

There are the presence of variables such as the supply of liquid, multi-tracking, use of oxytocin on the delivery, privacy, the partner's presence, providing information to the laboring woman and companion, empathic support of professionals, adopting not supine positions in delivery, fetal monitoring by intermittent auscultation and skin contact between mother and baby highlighted. In contrast, there was low use of the partograph, intravenous infusion of maintenance, administration of oxytocin and performing vaginal rings repeatedly, especially by more than one professional.

From this perspective, it is necessary to instigate reflection on obstetrical care to encourage the adoption of best practices and to propose the reduction of interventionist conduct, which is still present.

Moreover, the benefits of the study included the preparation of informative banner that was made available for setting the PPP environment. This contains explanations of the BPAPN to promote access to knowledge of women's rights during care delivery. Also, the results will help to improve services to women treated at $\mathrm{UH}$, to instigate reflection and (re) orientation of care provided to pregnant women.

The work offers important evidence for care evaluation and to raise awareness of professionals working there. However, as limitations mentioned, there is convenience sample, since the availability of data that would allow the formulation of sample calculations. Thus, it is suggested that further research using the referenced indicators are promoted in other realities to strengthen the discussion and reflection about the care provided to women and their newborns. 


\section{Author Statements}

The research followed the recommendations of Resolution 466/12 of the National Health Council (CNS) of Brazilian, with opinion approved by the Research Ethics Committee (CEP), the Faculty of Health Sciences in Trairí (FACIS), RN, Brazil, with number 1,034,398, and CAAE 43945415.4.0000.5568. The research has no funding and competing interests.

\section{References}

1. Silveira SC, Camargo B V, Crepaldi M A. Assistência ao parto na maternidade: representações sociais de mulheres assistidas e profissionais de saúde. Psicologia: reflexão e crítica. 2010; 23(1):1-10.

2. Santos RAA, Melo MCP, Cruz DD. Trajetória de humanização do parto no Brasil a partir de uma revisão integrativa de literatura. Caderno de Cultura e Ciência. 2015; 13(2):76-89.

3. Leister N, Riesco MLG. Assistência ao parto: História oral de mulheres que deram à luz nas décadas de 1940 a 1980. Texto Contexto Enferm. 2013; 22(1):166-174.

4. Brasil. Ministério da Saúde. Secretaria de Políticas de Saúde. Área Técnica de Saúde da Mulher. Parto, aborto e puerpério: assistência humanizada à mulher. Brasília (DF): Ministério da Saúde. 2001; 199 p.

5. Giglio MRP, França E, Lamouner JA. Avaliação da qualidade da assistência ao parto normal. RevBrasGinecolObstet. 2011; 33(10):297-304

6. Silva FMB, Paixão TCR, Oliveira, SMJV, Leite JS, Riesco MLG, Osava RH. Assistência em um centro de parto segundo as recomendações da Organização Mundial de Saúde. 2013; 47(5):1031-1038.

7. Patah LEM. Modelos de assistência ao parto e taxa de cesárea em diferentes países. Revista Saúde Pública. 2011; 45(1):185194.

8. Organização Mundial da Saúde. Saúde Materna e Neonatal. Unidade Maternidade Segura, Saúde Reprodutiva e da Família Assistência ao parto normal: um guia prático. Genebra. 2011.

9. World Health Organization. Principles of perinatal care: the essential antenatal, perinatal, and postpartum care course. Geneva: WHO. 2002

10. Handady SO, HajarSakin HH, Alawad AAM. An Assessment of Intra Partum Care Provided to Women in Labor at Omdurman Maternity Hospital in Sudan and Their Level of Satisfaction with It. International Journal of Public Health Research. 2015; 3(5):218-222.
11. Porto AMF, Amorim MMR, Souza ASR. Assistência ao primeiro período de trabalho de parto baseada em evidências. Femina. 2010; 38(10):527-537.

12. Pereira ALF, Nagipe SFSA, Lima GPV, Gouveia MSF.. Cuidados e resultados da assistência na sala de relaxamento de uma maternidade pública, Rio de Janeiro, Brasil. Texto Contexto Enferm. 2012; 21(3):566-573.

13. Hatem M, Sandall J, Devane D, Soltani H, Gates S. Midwife-led versus other models of care for childbearing women. In: The Cochrane Library 1. 2010.

14. Braga GC, Clementino STP, Luz PFN, Scavuzzi A, Noronha Neto C, Amorim MM R..Risk factors for episiotomy: a case-control study. Rev Assoc Med Bras. 2014; 60(5):465-472.

15. Francisco AM, Kinjo MH, Bosco CS, Silva RL, Mendes EPB, Oliveira SMJV. Associação entre trauma perineal e dor em primíparas. RevEscEnferm USP. 2014; 48(esp):40-45.

16. Almeida OSC, Gama ER, Bahiana PM. Humanização do parto: atuação dos enfermeiros. Revista Enfermagem Contemporânea. 2015; 4(1):79-90.

17. Lucas MTB, Rocha MJF, Costa KMM, Oliveira GG, Melo JO. Nursing care during labor in a model maternity unit: crosssectional study. Online braz j nurs [internet] 2015; 14 (1):3240. Available from: http://www.objnursing.uff. br/index.php/ nursing/article/view/5067

18. Sandin-Böjo AK, Kvist LJ. Care in labor: a Swedish survey using the Bologna score. Birth. 2008; 35(4):321-328.

19. Piantino DG, Filogonio OS, Novo JLVG. Qualificação da assistência ao parto normal em primíparas. Revista da Faculdade de Ciências Médicas de Sorocaba. 2014; 16 (supl). Available from: http://revistas.pucsp.br/index.php/RFCMS/article/view/21039

20. Rebello MTMP, Rodrigues Neto JF. A humanização da assistência ao parto na percepção de estudantes de medicina. Revista Brasileira de Educação Médica. 2012; 36(2):188-197.

21. Leal MC, Pereira APE, Domingues RMSM, Theme Filha MM, Dias $M A B$, Nakamura-Pereira M. Intervenções obstétricas durante o trabalho de parto e parto em mulheres brasileiras de risco habitual. Cad Saúde Pública. 2014; 30(sup):17-32.

22. Hofmeyr GJ. Evidence-based intrapartum care. Best Pract Res Clin Obstet Gynaeco. 2005; I19(1):103-15.

23. ACOG. Committee on Obstetric Practice. Committee opinion. Induction of labor for vaginal birth after caesarean delivery. Obstet Gyneco. 2010; 199(4):679-80.

24. Diniz CSG, D’Orsi E, Domingues RMSM, Torres JA, Dias $M A B$, Schneck $C A$ et al. Implementação da presença de acompanhantes durante a internação para o parto: dados da pesquisa nacional Nascer no Brasil. Cad Saúde Pública. 2014: 30(supl):140-53

25. Oliveira LMN, Cruz AGC. A Utilização da Bola Suíça na Promoção do Parto Humanizado. Revista Brasileira de Ciências da Saúde. 2014; 18(2):175-80. 
26. Organização Mundial da Saúde. Recomendações da OMS para a prevenção e tratamento da hemorragia pós-parto. Biblioteca da OMS. 2014. 81 p.

27. Moreira MEL, Gama SGN, Pereira APE, Silva AAM, Lansky S, Pinheiro RS. Práticas de atenção hospitalar ao recém-nascido saudável no Brasil. Cad Saúde Pública. 2014; 30(supl):128-39.

28. Cecatti JG. Crenças e crendices sobre as atuais intervenções durante o trabalho de parto e parto no Brasil. Cad Saúde Pública. 2014; 30(sup):33-5.

29. Aguilar RR, Fuentes GM., Aisa LM, Acosta VG, Martinez LD. et al. Rotura uterina en gestante con cesárea anterior trasmaniobra de Kristeller. Reporte de caso. Ver Chil Obstet Ginecol. 2014; 79(2): 111-4

30. Cesar MAP, Leite JM, Muniz RCC, Ortiz J. A. Distúrbios evacuatórios em primigestas após parto normal: estudo clínico. Rev Bras Coloproct. 2011; 31(2):126-30.

31. Serruya SJ. A arte de não fazer o errado e fazer o certo!. Cad Saúde Pública. 2014: 30(sup):17-47.

Publish in International Archives of Medicine

International Archives of Medicine is an open access journal publishing articles encompassing all aspects of medical science and clinical practice. IAM is considered a megajournal with independent sections on all areas of medicine. IAM is a really international journal with authors and board members from all around the world. The journal is widely indexed and classified Q2 in category Medicine. 